N. Lokhman ${ }^{1}$, Dr. Sc. (Econ.), Assoc. Prof., orcid.org/0000-0002-0116-2525,

V.Serebrenikov ${ }^{1}$, Cand. Sc. (Tech.), Assoc. Prof., orcid.org/0000-0002-5490-5601, T. Beridze ${ }^{2}$, Cand. Sc. (Tech.), Assoc. Prof., orcid.org/0000-0003-2509-3242, A. Cherep 3 , Dr. Sc. (Econ.), Prof., orcid.org/0000-0001-5253-7481, I. Dashko², Cand. Sc. (Econ.), Assoc. Prof., orcid.org/0000-0001-5784-4237
1 - Donetsk National University of Economics and Trade named after Mykhailo Tugan-Baranovsky, Kryvyi Rih, Ukraine

2 - Kryvyiy Rih faculty of Zaporizhzhia National University, Kryvyi Rih, Ukraine, e-mail: beridzet2016@gmail.com

3 - Zaporizhzhia National University, Zaporizhzhia, Ukraine

\title{
ANALYSIS OF ECONOMIC AND MATHEMATICAL MODELING OF INDUSTRIAL ENTERPRISE FUNCTIONING AT MULTICOLLINEARITY BASED ON PARAMETERIZATION
}

Purpose. Investigation of multicollinearity in multifactorial economic and mathematical regression models of activity of Inhulets Mining and Processing Plant and reduction of its negative influence based on application of the parameterization method.

Methodology. To reduce the negative impact of multicollinearity in multifactorial regression models, a technique is developed that is based on the transition from the function of several variables to its parametric representation by analyzing the correlation matrix between factors in order to eliminate mutual correlation.

Findings. Economic and mathematical modeling of the activity of the JSC Inhulets Mining and Processing Combine showed that the presence of multicollinearity when applying a multifactor regression model leads to a distortion of the obtained results, which reduces the practical value of the model. The application of the parametrization method made it possible to reduce the influence of multicollinearity by providing parametric representations of the economic-mathematical model of holding the real economic process. The application of the parameterization method makes it easier to construct an economic-mathematical mod$\mathrm{el}$ in the form of regression equations, to reduce the negative impact of multicollinearity in the implementation and meaningful analysis of features of economic and mathematical modeling using multivariate regression equations.

Originality. For the first time, the application of the parameterization method is proposed, which allows us to simplify the construction of an economic-mathematical model in the form of regression equations. Using the parameterization method allows reducing the uncertainty in the synthesis of multivariate regression equations, ensuring appropriate adequacy.

Practical value. The analysis of the obtained results of economic and mathematical modeling of the activity of the Inhulets Mining and Processing Plant based on significant statistical material using the developed algorithm of elimination of multicollinearity confirmed the effectiveness of the proposed approach. It is recommended to include the developed algorithm for elimination of multicollinearity by parametrization in the practice of management of economic activity of mining enterprises.

Keywords: mining, regression, multifactorial model, multicollinear, parameterization, financial activity

Introduction. The current state of Ukrainian mining industry is characterized by uncertainty, which is largely related to the economy. In this context, it is important to make a reasonable and timely assessment of the economic difficulties arising in the activities of mining enterprises. At the same time, the rapid development of events leads to the need to apply new approaches based on the use of modern mathematical apparatus with the use of the latest advances in IT technologies. One of the possible and effective approaches to solving emerging matters is the mathematical modeling method. It is clear that such modeling should adequately describe economic phenomena. Given that there is uncertainty in the studied economic phenomena in mathematical modeling, multivariate regression models are used in mathematical modeling, the question arises about the validity of the methods used in their construction. In particular, consideration of multicollinearity is a rather important matter. The construction of a multivariate regression model in the presence of multicollinearity leads to a distortion of the results obtained due to the correlation of the input variables. As a consequence, it is important to evaluate the impact of multicollinearity on the simulation result and, if possible, to eliminate it.

Literature review. Along with traditional statistical methods of data analysis, mathematical and statistical methods based on the known methodology are used in the study of real socio-economic phenomena and processes.

(C) Lokhman N., Serebrenikov V., Beridze T., Cherep A., Dashko I., 2020
The complexity of the use of mathematical and statistical methods involves a more complete disclosure of the essence, patterns and trends of specific phenomena and processes in order to adequately display the properties, reserves and prospects of development and ways of improvement.

Modern studies in the field of economics and its application in production are largely devoted to the analysis of the activity of enterprises through their economic and mathematical modeling. The works by scientists-economists M. I. Bakanov, A. D. Sheremet [1], R. S. Saifulin [2], G. V. Savitska [3] and others focus on efficiency and methods of its evaluation in economics. The content of mathematical modeling of economic activity is revealed in the works by scientists V.V. Vitlinskyi [4], M. O. Kyzym [5], M. O. Ponomarenko [6], O. M. Tryded [7]. In [8] it is proposed to use the value of average geometrical from the list of indicators as criterion of efficiency; according to the authors, the indicators define efficiency of management of industrial activity of enterprises. U. Mereste proposes to use matrix method to measure production efficiency [9]. According to the scientist, it will allow defining changes in the process of functioning and revealing reserves of improvement of activity of the enterprise. O. P. Levchenko notes that as a result of the analysis of components of economic activity of the enterprise, the most significant in the economic mechanism is the economic component [10].

Burova T.A. proposes to identify systems of indicators, which will allow forming an assessment of the efficiency of the enterprise [11]. Research on the methodology of statistical evaluation of the economic strategy of enterprises, which con- 
tributes to the formation of a model of their strategic development, is considered in [12]. Orientation to solving practical problems that can be described using a mathematical model is given in detail in [13].

Unsolved aspects of the problem. At the same time, attention is not fully paid to the influence of uncertainty and randomness in economic and mathematical modeling. In particular, this applies to the peculiarities of the application of multivariate regression models, where such an aspect as multicolinearity is quite simplified [14].

The purpose of the article is to investigate and eliminate the influence of multicollinearity on the result of economic and mathematical modeling when constructing a multivariate regression model by applying the parameterization method.

Results. There are various ways to identify multicollinearity using statistical methods. In particular, one such method is the Farrar-Glauber algorithm [4]. The peculiarity of the mentioned algorithm is that it allows identifying the presence of multicollinearity, but does not indicate an effective way to eliminate it. In this paper, an attempt is made to eliminate multicollinearity by presenting a multivariate regression model in a parametric form. Let us consider a linear three-factor regression model whose equation is

$$
y=a_{0}+a_{1} \cdot x_{1}+a_{2} \cdot x_{2}+a_{3} \cdot x_{3}+u,
$$

where $y$ is the output variable; $x_{1}, x_{2}, x_{3}$ are input variables (factors); $a_{0}, a_{1}, a_{2}, a_{3}$ are parameters; $u$ is perturbation.

Let us suppose that there is certain multicollinearity, that is, there is a correlation between the factors. According to the Farrar-Glauber algorithm, based on the submitted statistical material and using Pearson's criterion, the presence of multicollinearity is established. If there is no multicollinearity, then the parameters included in equation (1) are found, in particular by the ordinary least squares (OLS). In the presence of multicollinearity, options are possible. At the first stage, using the Farrar-Globe algorithm, we establish the existence of a correlation dependence of one factor on the other two. Let us consider the case where there is a correlation dependence of the factor $x_{3}$ on the factors $x_{1}$ and $x_{2}$, moreover, this dependence is confirmed by the statistical criterion, in this case, the Fisher criterion. Then it is natural to write a linear two-factor regression model in the form.

$$
x_{3}=b_{0}+b_{1} \cdot x_{1}+b_{2} \cdot x_{2}+u_{3},
$$

where $b_{0}, b_{1}, b_{2}$ are parameters; $u_{3}$ is perturbation.

Substituting (2) into equation (1), we obtain an equation that contains only two factors.

$$
y=a_{0}+a_{1} \cdot x_{1}+a_{2} \cdot x_{2}+a_{3} \cdot\left(b_{0}+b_{1} \cdot x_{1}+b_{2} \cdot x_{2}+u_{3}\right)+u,
$$

or

$$
y=c_{0}+c_{1} \cdot x_{1}+c_{2} \cdot x_{2}+u_{4},
$$

where

$$
\begin{array}{cl}
c_{0}=a_{0}+a_{3} \cdot b_{0} ; & c_{1}=a_{1}+a_{3} \cdot b_{1} ; \quad c_{2}=a_{2}+a_{3} \cdot b_{2} ; \\
& u_{4}=u+a_{3} \cdot u_{3} .
\end{array}
$$

The next step is to establish the existence of multicollinearity of the variables $x_{1}$ and $x_{2}$. To do this, we can use Student's criterion according to the Farrar-Glauber algorithm. If there is no multicollinearity, then there is no correlation between the variables $x_{1}$ and $x_{2}$. In this case, we obtain a system of two equations depending on two variables.

$$
\left\{\begin{array}{l}
y=c_{0}+c_{1} \cdot x_{1}+c_{2} \cdot x_{2}+u_{4} \\
x_{3}=b_{0}+b_{1} \cdot x_{1}+b_{2} \cdot x_{2}+u_{3}
\end{array} .\right.
$$

The use of OLS allows estimating the values of the parameters included in (4). The result is a system of equations

$$
\left\{\begin{array}{l}
\hat{y}=\hat{c}_{0}+\hat{c}_{1} \cdot x_{1}+\hat{c}_{2} \cdot x_{2} \\
\hat{x}_{3}=\widehat{b_{0}}+\widehat{b_{1}} \cdot x_{1}+\widehat{b_{2}} \cdot x_{2}
\end{array},\right.
$$

where $\hat{c}_{0}, \hat{c}_{1}, \hat{c}_{2}, \widehat{b_{0}}, \hat{b}_{1}, \widehat{b_{2}}$ are values of the parameters found using OLS; $\hat{y}, \hat{x}_{3}$ are estimates of the source variable $y$ and factor $x_{3}$.

If multicollinearity is present, there is a correlation between the variables $x_{1}$ and $x_{2}$. The specification of such dependency can be set by the correlation field of variables $x_{1}$ and $x_{2}$. If there is a linear correlation relationship, then the regression equation can be written as

$$
x_{2}=d_{0}+d_{1} \cdot x_{1}+u_{5},
$$

where are parameters; is perturbation.

Substituting (5) into system (3) and taking into account (6), we obtain a system of three equations that depend on one variable

$$
\left\{\begin{array}{l}
y=e_{0}+e_{1} \cdot x_{1}+u_{6} \\
x_{2}=d_{0}+d_{1} \cdot x_{1}+u_{5} \\
x_{3}=f_{0}+f_{1} \cdot x_{1}+u_{7}
\end{array}\right.
$$

where $e_{0}=c_{0}+c_{3} \cdot d_{0} ; e_{1}=c_{1}+c_{2} \cdot d_{1} ; f_{0}=b_{0}+b_{2} \cdot d_{0} ; f_{1}=b_{1}+$ $+b_{2} \cdot d_{1} ; u_{6}=u_{4}+c_{2} \cdot u_{5} ; u_{7}=u_{3}+b_{2} \cdot u_{5}$.

The use of OLS allows estimating the values of the parameters included in (7). The result is a system of equations

$$
\left\{\begin{array}{l}
\hat{y}=\hat{e}_{0}+\hat{e}_{1} \cdot x_{1} \\
\hat{x}_{2}=\widehat{d_{0}}+\widehat{d_{1}} \cdot x_{1}, \\
\hat{x}_{3}=\widehat{f_{0}}+\widehat{f_{1}} \cdot x_{1}
\end{array}\right.
$$

where $\hat{e}_{0}, \hat{e}_{1}, \widehat{d}_{0}, \widehat{d}_{1}, \widehat{f}_{0}, \widehat{f}_{1}$ are values of the parameters found using OLS; $\hat{y}, \hat{x}_{2}, \hat{x}_{3}$ are estimates of the source variable $y$ and factors $x_{2}$ and $x_{3}$.

The systems of equations (5) and (8) allow representing the three-factor regression model (1) in parametric form, thus eliminating multicollinearity.

In the general case, if the $n$-factor regression model is considered, then, in the presence of multicollinearity, the transition to a parametric representation of the regression model sequentially from $n-1$ parameters to one parameter is carried out in accordance with the above algorithm, if possible. Such representation of the $n$-factor regression model will eliminate the negative impact of multicollinearity.

The application of the developed algorithm on the example of financial activity analysis of Inhulets Mining Combine (InMC) of Kryvyi Rih city [15, 16] is presented below. Table 1 provides statistical material according to the InMC.

Based on economic considerations, the three-factor regression model of income $(Y)$ dependence on three factors: labor costs $\left(X_{1}\right)$, current assets value $\left(X_{2}\right)$ and residual value $\left(X_{3}\right)$, is to be found in the form of a production function of power form.

$$
y=a_{0} \cdot x_{1}^{a_{1}} \cdot x_{2}^{a_{2}} \cdot x_{3}^{a_{3}} \cdot u
$$

where $a_{0}, a_{1}, a_{2}, a_{3}$ are parameters; $u$ is perturbation

We reduce equation (8) to a linear form by taking logarithms.

$$
\ln y=\ln a_{0}+a_{1} \cdot \ln x_{1}+a_{2} \cdot \ln x_{2}+a_{3} \cdot \ln x_{3}+\ln u .
$$

In the new notations, equation (9) takes the form.

$$
z=a+a_{1} \cdot t_{1}+a_{2} \cdot t_{2}+a_{3},
$$

where

$$
z=\ln y ; \quad a=\ln a_{0} ; \quad t_{i}=\ln x_{i}(i=1,2,3) ; \quad w=\ln u .
$$


Statistical data on the production activities of the InMC enterprise

\begin{tabular}{|c|c|c|c|c|}
\hline Years & $\begin{array}{l}\text { Income }(Y) \\
\text { (unit of currency) }\end{array}$ & $\begin{array}{l}\text { Labor costs }\left(X_{1}\right) \\
\text { (unit of currency) }\end{array}$ & $\begin{array}{l}\text { Current assets value }\left(X_{2}\right) \\
\text { (unit of currency) }\end{array}$ & $\begin{array}{l}\text { Residual cost }\left(X_{3}\right) \\
\text { (unit of currency) }\end{array}$ \\
\hline 2001 & 796086 & 72498 & 378681 & 821313 \\
\hline 2002 & 886660 & 90422 & 348862 & 792836 \\
\hline 2003 & 1136460 & 118874 & 525939 & 915598 \\
\hline 2004 & 1446530 & 146511 & 406689 & 735313 \\
\hline 2005 & 2053653 & 207203 & 835021 & 812229 \\
\hline 2006 & 2084934 & 249876 & 852886 & 1012412 \\
\hline 2007 & 2998135 & 306953 & 1617929 & 1228221 \\
\hline 2008 & 6441396 & 317326 & 6726606 & 1312242 \\
\hline 2009 & 4384200 & 287365 & 5632716 & 4117950 \\
\hline 2010 & 8897838 & 338240 & 7225286 & 4041718 \\
\hline 2011 & 9875431 & 342604 & 11822216 & 4361040 \\
\hline 2012 & 9986708 & 335975 & 12263759 & 6506394 \\
\hline 2013 & 10352257 & 355995 & 17185530 & 6626622 \\
\hline 2014 & 11341151 & 405726 & 17032936 & 8940619 \\
\hline 2015 & 9489519 & 469718 & 25161471 & 10461594 \\
\hline 2016 & 11306531 & 517181 & 23501747 & 11449166 \\
\hline 2017 & 15711286 & 667177 & 35096304 & 11570129 \\
\hline 2018 & 18706815 & 926033 & 40843517 & 11874357 \\
\hline
\end{tabular}

We transform the data of Table 1 according to formulas (10) (Table 2) and use the OLS to find the parameters. As a result, model (10) will take the form

$$
z=3.27+0.45 \cdot t_{1}+0.516 \cdot t_{2}-0.091 \cdot t_{3} .
$$

In this case, the coefficient of determination amounted to $R^{2}=0.973$ and Fisher's criterion $-F=132$. Given that the critical value of the Fisher criterion is equal to $F=132>3.59$, we conclude that the regression equation is significant (10).

However, taking into account that the regression model (10) is multivariate, it is possible to distort the obtained results.
First of all, this may be due to the existence of multicollinearity. Therefore, it is necessary to check for multicollinearity. For this purpose, we use the Farrar- Glauber algorithm. Let us present the initial data in a standardized form according to the formulas

$$
t_{j k}^{*}=\frac{t_{j k}-\bar{t}_{k}}{s_{k}},
$$

where $\overline{t_{k}}$ is the average value $t_{j k} ; s_{k}$ is standard deviation.

The results of the calculations are presented in Table 2.

Table 2

Results of calculations by the Farrar-Glauber algorithm

\begin{tabular}{|c|c|c|c|c|c|c|c|c|c|c|c|}
\hline Years & $z$ & $t_{1}$ & $t_{2}$ & $t_{3}$ & $t_{1}^{*}$ & $t_{2}^{*}$ & $t_{3}^{*}$ & $t_{1}^{*} \cdot t_{2}^{*}$ & $t_{1}^{*} \cdot t_{3}^{*}$ & $t_{2}^{*} \cdot t_{3}^{*}$ & $t_{1}^{*} \cdot t_{1}^{*}$ \\
\hline 2001 & 13.59 & 11.19 & 12.84 & 13.62 & -2.08 & -1.28 & -0.99 & 2.66 & 2.07 & 1.27 & 4.33 \\
\hline 2002 & 13.70 & 11.41 & 12.76 & 13.58 & -1.69 & -1.33 & -1.03 & 2.25 & 1.74 & 1.37 & 2.87 \\
\hline 2003 & 13.94 & 11.69 & 13.17 & 13.73 & -1.22 & -1.07 & -0.89 & 1.30 & 1.08 & 0.95 & 1.48 \\
\hline 2004 & 14,19 & 11.90 & 12.92 & 13.51 & -0.85 & -1.23 & -1.10 & 1.05 & 0.94 & 1.36 & 0.72 \\
\hline 2005 & 14.54 & 12.24 & 13.64 & 13.61 & -0.24 & -0.78 & -1.00 & 0.19 & 0.24 & 0.79 & 0.06 \\
\hline 2006 & 14.55 & 12.43 & 13.66 & 13.83 & 0.09 & -0.77 & -0.79 & $-0,07$ & -0.07 & 0.60 & 0.01 \\
\hline 2007 & 14.91 & 12.63 & 14.30 & 14.02 & 0.45 & -0.37 & -0.59 & -0.17 & -0.27 & 0.22 & 0.20 \\
\hline 2008 & 15.68 & 12.67 & 15.72 & 14.09 & 0.51 & 0.52 & -0.53 & 0.26 & -0.27 & -0.28 & 0.26 \\
\hline 2009 & 15.29 & 12.57 & 15.54 & 15.23 & 0.33 & 0.41 & 0.61 & 0.14 & 0,20 & 0,25 & 0.11 \\
\hline 2010 & 16.00 & 12.73 & 15.79 & 15.21 & 0.62 & 0.57 & 0.59 & 0.35 & 0.37 & 0.33 & 0.38 \\
\hline 2011 & 16.11 & 12.74 & 16.29 & 15.29 & 0.64 & 0.88 & 0.67 & 0.56 & 0.43 & 0.58 & 0.41 \\
\hline 2012 & 16.12 & 12.73 & 16.32 & 15.69 & 0.61 & 0.90 & 1.06 & 0.55 & 0.64 & 0.95 & 0.37 \\
\hline 2013 & 16.15 & 12.78 & 16.66 & 15.71 & 0.71 & 1.11 & 1.08 & 0.79 & 0.77 & 1.20 & 0.50 \\
\hline 2014 & 16.24 & 12.91 & 16.65 & 16.01 & 0.94 & 1,10 & 1.38 & 1.03 & 1.29 & 1.52 & 0.88 \\
\hline 2015 & 16.07 & 13.06 & 17.04 & 16,16 & 1.19 & 1.35 & 1.53 & 1.61 & 1.83 & 2.07 & 1.43 \\
\hline 2016 & 16.24 & 13.16 & 16.97 & 16.25 & 0.90 & 0.98 & 1.22 & 0.89 & 1.11 & 1.20 & - \\
\hline 2017 & 16.57 & 13.41 & 17.37 & 16.26 & 1.29 & 1.21 & 1.23 & 1.56 & 1.59 & 1.49 & - \\
\hline 2018 & 16.74 & 13.74 & 17.53 & 16.29 & 1.78 & 1.30 & 1.26 & 2.31 & 2.24 & 1.63 & - \\
\hline amount & 15.37 & 12.55 & 14.29 & 14.89 & 0 & 0 & 0 & - & - & - & - \\
\hline stand. deviation & 1.04 & 0.66 & 1.72 & 1.11 & - & - & $k . c o r$ & 0.920 & 0.850 & 0.957 & - \\
\hline
\end{tabular}


According to Table 2, we make up the correlation matrix

$$
r=\left(\begin{array}{ccc}
1 & 0.833 & 0.732 \\
0.833 & 1 & 0.878 \\
0.732 & 0.878 & 1
\end{array}\right)
$$

We calculate the determinant of the correlation matrix

$$
|r|=0.07 \text {. }
$$

Since the determinant is quite small, we can conclude that there are multicollinearity factors.

According to the Farrar-Glauber algorithm, we compute $\chi^{2}$ - the statistics by the formula

$$
\chi^{2}=-\left(n-1-\frac{1}{6}(2 p+1)\right) \ln r .
$$

Given that $n=15, p=3$ and (12), we find by formula (13)

$$
\chi^{2}=32.4 \text {. }
$$

Critical value of the Pearson criterion is equal to

$$
\chi_{k p}^{2}\left(\frac{p(p-1)}{2} ; \alpha\right)=\chi_{k p}^{2}(3 ; 0.05)=7.81
$$

If

$$
\chi^{2}=32.4>7.81
$$

then multicollinearity takes place.

Then, we determine the relationship between the selected factor and the other two using the Fisher criterion. We find a matrix inverse of the correlation matrix (11),

$$
r^{-1}=\left(\begin{array}{ccc}
3.27 & -2.72 & -0.004 \\
-2.72 & 6.644 & -3.845 \\
-0.004 & -3.845 & 4.381
\end{array}\right)
$$

We calculate the Fisher criterion by the formula

$$
F_{k}=\left(c_{k k}-1\right) \frac{n-p}{p-1},
$$

where $c_{k k}$ is diagonal elements of the matrix (14).

Substituting in (15) the diagonal elements of the matrix (14), we find

$$
F_{1}=13.62 ; \quad F_{2}=33.87 ; \quad F_{3}=20.28 .
$$

The critical value of the Fisher criterion is

$$
F_{k p}(\alpha, p-1, n-p)=F_{k p}(0.05 ; 2 ; 12)=3.89 \text {. }
$$

Since $F_{1}=13.62>3.89 ; F_{2}=33.87>3.89 ; F_{3}=20.28>3.89$ then each factor correlates with the other two.

Given that $t_{1}$ correlates with $t_{2}$ and $t_{3}$, the regression equation can be written as

$$
t_{1}=b_{0}+b_{1} \cdot t_{2}+b_{2} \cdot t_{3} .
$$

Using OLS, we find

$$
t_{1}=9.24+0.482 \cdot t_{2}-0.277 \cdot t_{3} .
$$

Thus, $R^{2}=0.824, F=28.1, F_{k p}(0.05 ; 12 ; 2)=3.89$. Since $28.1>3.89$, equation (18) is significant.

Substitute (17) into (10)

$$
z=a+a_{1}\left(b_{0}+b_{1} \cdot t_{2}+b_{2} \cdot t_{3}\right)+a_{2} \cdot t_{2}+a_{3} \cdot t_{3},
$$

or

$$
z=c_{0}+c_{1} \cdot t_{2}+c_{2} \cdot t_{3} .
$$

Consider the correlation $t_{2}$ and $t_{3}$. In this case, the correlation matrix takes the form

$$
\mathbf{r}=\left(\begin{array}{cc}
1 & 0.878 \\
0.878 & 1
\end{array}\right)
$$

The determinant of the matrix (20) is equal to

$$
|r|=\left|\begin{array}{cc}
1 & 0.878 \\
0.878 & 1
\end{array}\right|=0.229
$$

According to the Farrar-Glauber algorithm, we compute $\chi^{2}-$ the statistics according to formula (13). Given that $n=15$, $p=3$ and (21), by formula (13) we calculate $\chi^{2}=17.9$. According to the table, we find $(2 ; 0.05)=4.303$. Since $17.9>4.303$, multicollinearity is present. Therefore, we can write the regression equation between $t_{2}$ and $t_{3}$. To specify the regression equation, we construct a correlation field (Figure).

Analysis of the correlation field in Figure shows that there is a linear correlation. This allows us to record the regression equation as

$$
t_{3}=\gamma_{0}+\gamma_{1} \cdot t_{2}
$$

Using OLS, we find

$$
t_{3}=5.79+0593 \cdot t_{2} .
$$

Thus $R^{2}=0.886, F=100, F_{c o r}(0.05 ; 13 ; 1)=4.67$. Since $100>4.67$, then equation (23) is significant. Substitute (22) into (19)

or

$$
z=c_{0}+c_{1} \cdot t_{2}+c_{2} \cdot\left(d_{0}+d_{1} \cdot t_{2}\right),
$$

$$
z=\alpha_{0}+\alpha_{1} \cdot t_{2}
$$

Considering (24), formula (17) takes the form

$$
t_{1}=b_{0}+b_{1} \cdot t_{2}+b_{2} \cdot\left(d_{0}+d_{1} \cdot t_{2}\right),
$$

or

$$
t_{1}=\beta_{0}+\beta_{1} \cdot t_{2}
$$

Using OLS, we find

$$
t_{1}=7.64+0.318 \cdot t_{2}
$$

Thus $R^{2}=0.797, F=51, F_{c o r}(0.05 ; 13 ; 1)=4.67$. Since $51>4.67$, then equation (26) is significant.

Finally, let us consider equation (28). Using OLS, we find

$$
z=6.15+0.604 \cdot t_{2} .
$$

Thus, $R^{2}=0.956, F=281, F_{\text {cor }}(0.05 ; 13 ; 1)=4.67$. Since $281>4.67$, then equation (27) is significant.

Thus, the system of equations $(27,26$ and 23$)$, which determines the model of regression of financial activity of InMC, is obtained.

$$
\left\{\begin{array}{l}
z=6.15+0.604 \cdot t_{2} \\
t_{1}=7.64+0.318 \cdot t_{2} \\
t_{3}=5.79+0.593 \cdot t_{2}
\end{array}\right.
$$

From a mathematical point of view, there is a parametric representation of the regression model. In this case, the basic parameter is a variable $t_{2}$.

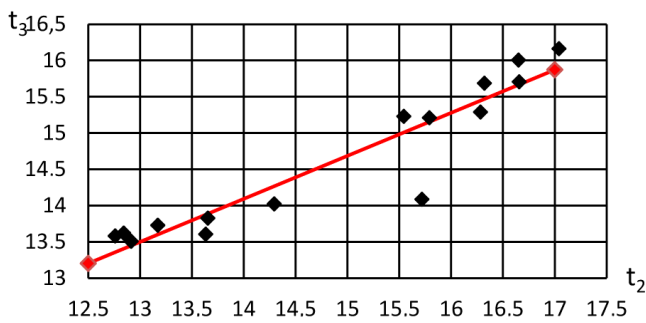

Fig. Correlation field and regression line 
It is clear that any of the variables that are more economically viable can be selected as the base parameter.

Given the substitution (10), the system (28) can be written in a power form

$$
\begin{cases}y=469 \cdot x_{2}^{0.604}, & \left(R^{2}=0.874, F=90\right) \\ x_{1}=2076 \cdot x_{2}^{0.318}, & \left(R^{2}=0.832, F=64.4\right) . \\ x_{3}=328 \cdot x_{2}^{0.593}, & \left(R^{2}=0.858, F=78.5\right)\end{cases}
$$

Since each of the calculated values of the Fisher criterion in (29) is greater than this value, we conclude that the equations found are significant.

In conclusion, it should be emphasized that the construction of the model of multivariate regression allows not only taking into account the multicollinearity of the factors, but also calculating the values of these factors, depending on the value of the basic factor taken as a parameter.

Conclusions. Market relations in Ukraine require the use of modern management methods in the economy, which are based on economic and mathematical modeling. Particular attention should be paid to the adequacy of mathematical models, since their synthesis occurs when taking into account uncertainties. Considering that multivariate regression analysis is used in the construction of models, multicollinearity is significantly influenced by the correctness of the conclusions drawn. The elimination of multicollinearity by applying a parametric approach allowed avoiding this negative influence. In addition, the developed algorithm made it possible to simplify the regression model for its further application. The efficiency of the proposed algorithm is confirmed on the example of the economic activity analysis of Inhulets Mining Combine.

\section{References.}

1. Sheremet, A. D. (2014). A complex analysis of sustainable development indicators of an enterprise economics. Ekonomycheskii analyz: teoriia i praktika, 45(396), 2-10.

2. Sheremet, A. D., Saifulin, R. S., \& Negashev, E. V. (2016), The technique of financial analysis. Moscow: INFRA-M.

3. Savitskaia, H.V. (2014). Analysis of the effectiveness and risks of entrepreneurial activity: Methodological aspects: monograph. Moscow: NYTs YNFRA.

4. Vitlinskyi, V.V. (2017). Methodological principles of risk modeling in the system of economic security, Modeliuvannia ta informatsiini systemy $v$ ekonomitsi, 94, 14-27.

5. Kyzym, M., \& Khaustova, V. (2015). Cluster format for arranging and implementing industrial policy. Acta Innovations, 17, 30-40.

6. Ponomarenko, V. S., \& Hontareva, I. V. (2015). Methodology of complex evaluation of enterprise development efficiency: monograph. Kharkiv: KhNEU im. S. Kuznetsia.

7. Trydied, O. M., \& Dziebko, I. P. (2015). Implementation of strategic management accounting as a tool for increasing the company's competitiveness. Problems of Theory and Methodology of Accounting, Control and Analysis, 1(19), 376-382.

8. Udalykh, O.O. (2016). Budgeting as a method of economic management of the enterprise. Finansovi doslidzhennia, 1, 96-100. 9. Leoht'eva, L.S., \& Orlova, L. N. (2016). Using the principles of matrix modeling for a comprehensive assessment of the effectiveness of institutional changes in entrepreneurship. Mir. Modernizatsiia. Innovatsiia. Razvitiie, 7(1), 97-101.

10. Levchenko, O.M., Tkachuk, O.V., \& Tsarenko, I.O. (2017). Innovation-integrated structures in the modern economy: their classification. Efektyvna ekonomika, (10). Retrieved from http://www.economy.nayka.com.ua/?op=1\&z=5791.

11. Burkova, L.A. (2014). Theoretical bases for assessing the efficiency of enterprises and ways of its improvement. Innovatsiina ekonomika, 4, 145-153.

12. Beridze, T. M. (2016). Statistical monitoring in the enterprise strategic management system: monograph. Kremenchug: PP Scherbatykh O.V.
13. Takha, Khemdy A. (2019). Operations research. Moscow: Vyliams Y. D.

14. Beridze, T.M., Serebrenikov, V.M., \& Lokhman, N.V. (2018). Monitoring of production activity of enterprises of Kryvyi Rih region. Ekonomika ta suspilstvo, 15, 213-218.

15. State Statistics Service of Ukraine (n.d.). Operating rate of Inhulets Mining Combine. Retrieved from http://www.ukrstat. gov.ua/operativ/oper_new.html.

16. SMIDA (n.d.). Operating rate of Inhulets Mining Combine. Retrieved from http://smida.gov.ua/.

\section{Аналіз економіко-математичного моделювання функціонування промислового підприємства при мультиколлінеарності на основі параметризації}

\author{
Н. В. Лохман ${ }^{1}$, В. М. Серебреников ${ }^{1}$, T. М. Берідзе ${ }^{2}$, \\ A. В. Череп ${ }^{3}$, I. М. Дашко ${ }^{2}$
}

1 - Донецький національний університет економіки і торгівлі імені Михайла Туган-Барановського, м. Кривий Ріг, Україна

2 - Криворізький факультет Запорізького національного університету, м. Кривий Ріг, Україна, e-mail: beridzet2016@gmail.com

3 - Запорізький національний університет, м. Запоріжжя, Україна

Мета. Дослідження мультиколінеарності в багатофакторних регресійних економіко-математичних моделях діяльності Інгулецького гірничо-збагачувального комбінату та зменшення іiї негативного впливу на основі застосування методу параметризації.

Методика. Для зменшення негативного впливу мультиколлінеарності в багатофакторних регресійних моделях розроблена методика, що заснована на переході від функції декількох змінних до її параметричного подання шляхом аналізу кореляційної матриці між факторами 3 метою усунення взаємної кореляції.

Результати. Економіко-математичне моделювання діяльності ПрАТ «Інгулецький гірничо-збагачувальний комбінат» показало, що наявність мультиколінеарності при застосуванні багатофакторної регресійної моделі призводить до спотворення отриманих результатів, це знижує практичну цінність моделі. Застосування методу параметризації дозволило зменшити вплив мультиколінеарності, надавши параметричного подання економіко-математичній моделі утримання реального економічного процесу. Застосування методу параметризації дозволяє спростити побудову економіко-математичної моделі у вигляді регресійних рівнянь, зменшити негативний вплив мультиколінеарності при реалізації та змістовному аналізі особливостей економіко-математичного моделювання за допомогою багатофакторних регресійних рівнянь.

Наукова новизна. Уперше запропоноване застосування метода параметризації, що дозволяє спростити побудову економіко-математичної моделі у вигляді регресійних рівнянь. Використання метода параметризації дозволяє зменшити невизначеність при синтезі багатофакторних регресійних рівнянь, забезпечивши відповідну адекватність.

Практична значимість. Аналіз отриманих результатів економіко-математичного моделювання діяльності Інгулецького гірничо-збагачувального комбінату на значному статистичному матеріалі із застосуванням розробленого алгоритму усунення мультиколінеарності підтвердив дієвість запропонованого підходу. Рекомендується включити розроблений алгоритм із усунення мультико- 
лінеарності шляхом параметризації до практики управління економічною діяльністю гірничорудних підприємств.

Ключові слова: гірничорудна промисловість, регресія, багатофакторна модель, мультиколінеарніть, параметризація, фінансова діяльність

\section{Анализ экономико-математического моделирования деятельности промышленного предприятия при мультиколлинеарности на основе параметризации}

\section{Н. В. Лохман ${ }^{1}$, В. М. Серебреников ${ }^{1}$, Т. М. Беридзе $e^{2}$} А. В. Череп ${ }^{3}$, И. Н. Дашко ${ }^{2}$

1 - Донецкий национальный университет экономики и торговли имени Михаила Туган-Барановского, г. Кривой Рог, Украина

2 - Криворожский факультет Запорожского национального университета, г. Кривой Рог, Украина, e-mail: beridzet2016@gmail.com

3 - Запорожский национальный университет, г. Запорожье, Украина

Цель. Исследование мультиколлинеарности в многофакторных регрессионных экономико-математических моделях деятельности Ингулецкого горно-обогатительного комбината и уменьшения ее негативного влияния на основе применения метода параметризации.

Методика. Для уменьшения негативного влияния мультиколлинеарности в многофакторных регрессионных моделях разработана методика, которая основана на переходе от функции нескольких переменных к ее параметрическому представлению путем анализа корреляционной матрицы между факторами с целью устранения взаимной корреляции.
Результаты. Экономико-математическое моделирование деятельности ЧАО «Ингулецкий горно-обогатительный комбинат» показало, что наличие мультиколлинеарности при применении многофакторной регрессионной модели приводит к искажению полученных результатов, это снижает практическую ценность модели. Применение метода параметризации позволило уменьшить влияние мультиколлинеарности, придав параметрическому представлению экономико-математической модели содержание реального экономического процесса. Применение метода параметризации позволяет упростить построение экономико-математической модели в виде регрессионных уравнений, уменьшить негативное влияние мультиколлинеарности при реализации и содержательном анализе особенностей экономико-математического моделирования с помощью многофакторных регрессионных уравнений.

Научная новизна. Впервые предложено применение метода параметризации, что позволяет упростить построение экономико-математической модели в виде регрессионных уравнений. Использование метода параметризации позволяет уменьшить неопределенность при синтезе многофакторных регрессионных уравнений, обеспечив соответствующую адекватность.

Практическая значимость. Анализ полученных результатов экономико-математического моделирования деятельности Ингулецкого горно-обогатительного комбината на значительном статистическом материале с применением разработанного алгоритма устранения мультиколлинеарности подтвердил действенность предложенного подхода. Рекомендуется включить разработанный алгоритм по устранению мультиколлинеарности путем параметризации в практику управления экономической деятельностью горнорудных предприятий.

Ключевые слова: горнонорудная промышленность, регрессия, многофакторная модель, мультиколлинеарность, параметризация, финансовая деятельность

Recommended for publication by A. A. Turilo, Doctor of Economic Sciences. The manuscript was submitted 17.05.19. 